\title{
Ю.В. Щербинина
}

Московский педагогический государственный университет, 119991 г. Москва, Российская Федерация

\section{Образы русских писателей-классиков в живописи и графике XIX- XX веков (на примере Н.В. Гоголя и Ф.М. Достоевского)}

\begin{abstract}
Аннотация. В статье исследуется портретный образ писателя в контексте его биографии и творчества на примере Н.В. Гоголя и Ф.М. Достоевского. Предметом авторского внимания становятся различные способы визуальной репрезентации, традиционные приемы изображения и новейшие форматы портретирования в русской и европейской живописи и графике XIX-XX вв. К анализу привлекаются художественные произведения Александра Иванова, Ильи Репина, Василия Перова, Михаила Клодта, Дункана Гранта, Эмиля Филлы, Хуго Мора и других художников. В статье раскрываются также (на примере изучения биографии и творчества, анализа отдельных произведений Н.В. Гоголя и Ф.М. Достоевского) методический потенциал и дидактическая направленность этих работ. Автор приводит искусствоведческие интерпретации и философские комментарии, позволяющие использовать указанные работы в практике преподавания литературы. На основе анализа и обобщения педагогического опыта в статье постулируется насущная необходимость расширения средств наглядности в литературном образовании школьников, проблематизируется потребность обновления визуальных материалов для повышения эффективности изучения произведений литературной классики, стимулирования интереса школьников к чтению и дальнейшему знакомству и изучению творчества писателей, включенных в школьные программы. Автор статьи предлагает специальные вопросы и задания, нацеливающие учителя на изучение традиционного и новаторского портретного искусства и использования его на уроках литературы в старшей школе, а также рассматриваются потенциальные возможности его привлечения в исследовательской проектной деятельности учащихся.
\end{abstract}

Ключевые слова: Н.В. Гоголь, Ф.М. Достоевский, портрет писателя, визуальный образ, живопись и графика на уроках литературы

\section{J.V. Shcherbinina}

Moscow Pedagogical State University, Moscow, 119991, Russian Federation

\section{Images of Russian classical writers in the pictorial and graphic art of the XIX-XX centuries (using the example of N.V. Gogol and F.M. Dostoevsky)}

\begin{abstract}
The article examines the portrait image of the writer in the context of his biography and work on the example of N.V. Gogol and F.M. Dostoevsky. Various methods of visual representation, traditional methods of image and the latest portrait formats in the Russian and European painting and graphics of the 19th-20th centuries become the subject of the author's attention. Artistic works by Alexander Ivanov, Ilya Repin, Vasily Perov, Mikhail Klodt, Duncan Grant, Emile Filla, Hugo Mora and other artists are involved in the analysis. The article also reveals (on the example of studying biography and oeuvre, analyzing individual works of N.V. Gogol's and F.M. Dostoevsky's) the methodological potential and didactic orientation of these works. The author provides art criticism interpretations and philosophical commentaries that allow using these works in the practice of teaching literature. Based on the analysis and generalization of pedagogical experience, the article postulates the urgent need to expand the means of visualization in the literary education of schoolchildren. The article also problematizes
\end{abstract}


the need to update visual materials to increase the effectiveness of studying literary classics, stimulating the schoolchildren's interest in reading and further acquaintance and study of oeuvre of the writers included in the school curricula. The author of the article offers special questions and tasks that direct teachers to the study of traditional and innovative portrait art and its use in literature lessons in high school and considers the potential opportunities for its involvement in research project activities of students'.

Key words: N.V. Gogol, F.M. Dostoevsky, the portrait of the writer, the visual image, pictorial and graphic art at the lesson of literature 